\title{
Patterns of attack by herbivores on the tropical shrub Bauhinia brevipes (Leguminosae): Vigour or chance?
}

\author{
TAtiana Garabini CORNELISSEN and G. Wilson FERNANDES \\ Ecologia Evolutiva de Herbívoros Tropicais/DBG, CP 486, ICB/Universidade Federal de Minas Gerais, \\ 30161-970 Belo Horizonte MG, Brazil; e-mail: tatiana@icb.ufmg.br
}

Key words. Herbivores, chewing insects, galling insects, Curculionidae, Pantomorus, Naupactus, Cecidomyiidae, Contarinia, Leguminosae, Bauhinia, plant vigour hypothesis

\begin{abstract}
The plant vigour hypothesis (PVH) predicts that females of galling insects preferentially oviposit on the most vigorous plants or plant modules, where their offspring's performance is highest. In the years 1995 to 1998 , we evaluated the responses of species of two different guilds, two chewing species, Pantomorus sp. and Naupactus lar (Coleoptera: Curculionidae) and one galling species, Contarinia sp. (Diptera: Cecidomyiidae), to the length of shoots that were assumed to show the vigour of the tropical shrub Bauhinia brevipes (Leguminosae). The abundance of the chewing herbivores was not influenced by shoot length, since attack rates were randomly distributed among shoot length classes. The abundance of Contarinia galls increased with increasing shoot length, as proposed by the PVH. However, when we related the attack rate to unit length of shoot $(\mathrm{cm})$, which denotes the resource availability per unit length, there was no effect of shoot length on Contarinia sp. These data corroborate the idea of a continuum of responses to plant quality, even when different herbivores feed on the same host plant.
\end{abstract}

\section{INTRODUCTION}

Animal occurrence and feeding is influenced by plant geographical range and local abundance, their size, structural complexity and nutritional quality, secondary chemistry, and phenology, among other factors (Price et al., 1991). Any or all of these parameters are important in determining the consequences of animal feeding patterns and intensity (Crawley, 1989).

Studies on the effects of plant quality on the attack rates of herbivorous insects have shown opposite results that have been incorporated into two major hypotheses. The plant stress hypothesis (PSH) proposed by White (1984) and Mattson \& Haack (1987) argues that herbivore abundance is higher on stressed host plants. The mechanism accounting for this pattern would be a decrease in protein synthesis coupled with an increase in soluble amino acid content in plant tissue. Moreover, stressed plants are less able to produce chemical defenses (Rhoades, 1979), and stress, such as water shortage, hastens senescence of plant tissues, and translocated nutrients benefit insect herbivore nutrition, growth and survival (Prada et al., 1995). The term "stress" usually refers to plant performance, which is reduced below that achieved under optimal conditions (Price, 1991).

The host plant vigour hypothesis (PVH) predicts that insect herbivores, that oviposit close to where their offspring feed, and whose larvae develop best on rapidly growing plant parts, prefer to oviposit on vigorously growing plants and/or plant modules (Price et al., 1990; Price, 1991, 1994). The term "vigour" refers to plant performance, i.e., vigorously growing plants grow rapidly and are highly reproductive compared to others. Vigour is readily measured using such criteria as size of leaves, length of shoots produced in a particular season, number and size of flowers (Prada et al., 1995).

The PVH is not only an alternative way to explain herbivory patterns, which are not covered by the PSH, but a proposal to broaden the hypothesis: Vigorous and Stressed Plant Hypotheses are at opposite ends of a continuum.

In this study, we evaluated the effect of plant shoot length on insects feeding on Bauhinia brevipes Vog. (Leguminosae) in southeastern Brazil. We tested the hypothesis that herbivore attack is higher on more vigorous plant shoots for both chewing and galling herbivores on B. brevipes. In addition, the level of response of these guilds - chewing and galling herbivores - to different host plant shoot lengths was determined.

\section{MATERIAL AND METHODS}

\section{System}

Bauhinia brevipes is a cerrado (savanna) leguminous shrub, up to $3 \mathrm{~m}$ tall (Cornelissen et al., 1997), which flowers and fruits from June to August. Several galling and free-feeding insect herbivores attack this plant (Cornelissen et al., 1997). During this study, the chewing herbivores attacking Bauhinia were primarily Naupactus lar (Coleoptera: Curculionidae) and Pantomorus sp. (Coleoptera: Curculionidae) causing damage to leaf edges, and chewing circular holes in the lamina of the leaves. Seven undescribed species gall $B$. brevipes, a new species of Contarinia and two other undetermined species of Diptera: Cecidomyiidae, and four species gall the stems: one Cecidomyiidae, one Lepidoptera, and two Curculionidae (see Cornelissen et al., 1997; Fernandes, 1998; Cornelissen \& Fernandes, 1998). The undescribed species of Contarinia induces leaf galls on the adaxial leaf surface of $B$. brevipes. The spherical galls are covered with long red hairs and enclose a single chamber, containing one larva (Fernandes, 1998). 


\section{Study Site}

The study site was at the Estação Ecológica de Pirapitinga (IBAMA) in Três Marias-MG, southeastern Brazil. The biological station is a man-made island of 1100 ha in the Três Marias reservoir $\left(18^{\circ} 23^{\prime} \mathrm{S}, 45^{\circ} 20^{\prime} \mathrm{W}\right)$, which was built in 1965 , at an altitude of $560 \mathrm{~m}$ a.s.l. The average annual temperature at the study site varies from 20 to $22^{\circ} \mathrm{C}$, and the average annual precipitation is $1,600 \mathrm{~mm}$ (Goodland \& Ferri, 1979; Eiten, 1993). The vegetation is primarily cerrado (savanna), with three distinct physiognomies: cerradão, cerrado sensu strictu, and campo sujo (Azevedo et al., 1987). The cerrado sensu strictu is the primary vegetation type of the island, consisting of more than a hundred plant species from more than fifty families (Gonçalves-Alvim \& Fernandes, 2001). It is composed of trees and shrubs approximately $6 \mathrm{~m}$ in height, and an herbaceous layer.

\section{Sampling}

Patterns of herbivory were determined over a period of four consecutive years by randomly collecting 25 shoots of Bauhinia brevipes from around the canopy of 170 plants. The shoots were placed in plastic bags and taken to the laboratory where their length (to the nearest $\mathrm{mm}$ ), total number of leaves, number of galled leaves, number of galls, and number of leaves attacked by chewing insects, on each of the 15,116 shoots were determined. The shoot lengths were divided into shoot length classes of $3 \mathrm{~cm}$ ( $\mathrm{n}=20$ classes) (see Price, 1991). Shoot length was used as an indicator of plant vigour. This measure is consistent with the definition of vigour and applies to any plant or plant module that grows rapidly, and reaches a large size, relative to the mean growth rate and size reached by the population of plants or plant modules (Price, 1991). The attack rates of the chewing and galling herbivores were calculated as the relative number of attacked leaves and number of galls, respectively, per unit of shoot length $(\mathrm{cm})$, in an attempt to correct for the longest shoots having higher probability of being attacked (Gonçalves-Alvim et al., 1999).

\section{RESULTS}

More than 15,000 shoots and approximately 17,000 galls were sampled during the four years of study. Long shoots had more leaves than short shoots $(\log \mathrm{y}=0.412+$ $0.436 \log x ; r^{2}=0.64 ; F_{1,163}=278.98 ; P<0.0001 ;$ Fig. 1$)$. As predicted by the PVH, most shoots were concentrated in the shorter shoot length classes, and the longer shoots were rare (Fig. 2).

Variation in shoot length did not explain variation in the percentage of attack by chewing herbivores in 1995 (y $\left.=36.9-0.17 \mathrm{x} ; \mathrm{r}^{2}=0.16 ; \mathrm{F}_{1,16}=1.19 ; \mathrm{P}>0.05\right), 1996(\mathrm{y}=$ $\left.31.55-001 \mathrm{x} ; \mathrm{r}^{2}=0.01 ; \mathrm{F}_{1,16}=0.005 ; \mathrm{P}>0.05\right), 1997(\mathrm{y}=$ $\left.37.82+0.27 \mathrm{x} ; \mathrm{r}^{2}=0.18 ; \mathrm{F}_{1,16}=3.67 ; \mathrm{P}>0.05\right)$, or 1998 $\left(\mathrm{y}=19.51+0.21 \mathrm{x} ; \mathrm{r}^{2}=0.16 ; \mathrm{F}_{1,16}=2.92 ; \mathrm{P}>0.05 ;\right.$ Fig 3).

In contrast, variation in shoot length explained approximately $85.0 \%$ of the variation in the number of galls per shoot in $1995\left(\mathrm{r}^{2}=0.84 ; \mathrm{F}_{1,16}=85.08 ; \mathrm{P}<0.005\right), 74.0 \%$ in $1996\left(\mathrm{r}^{2}=0.74 ; \mathrm{F}_{1,16}=45.53 ; \mathrm{P}<0.005\right), 86.0 \%$ in $1997\left(\mathrm{r}^{2}=0.86 ; \mathrm{F}_{1,16}=104.35 ; \mathrm{P}<0.005\right)$, and $87.0 \%$ in $1998\left(r^{2}=0.87 ; F_{1,16}=105.93 ; P<0.005 ;\right.$ Fig 3$)$. However, when corrected for the fact that the longer shoots have more leaves, by dividing the number of galls by shoot length $(\mathrm{cm})$, none of the relationships were statistically significant $\left(1995: \mathrm{r}^{2}=0.01 ; \mathrm{P}>0.05 ; 1996: \mathrm{r}^{2}=\right.$

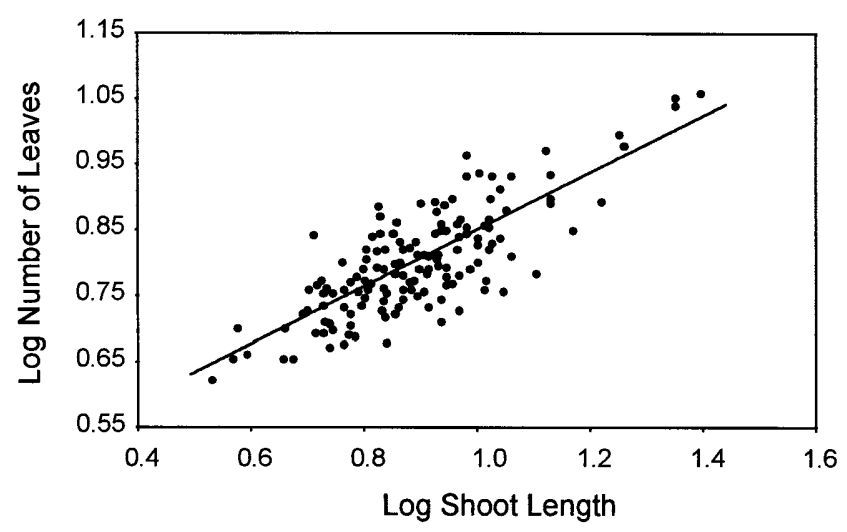

Fig. 1. Relationship between number of leaves and shoot length in B. brevipes. Data were log transformed.

$0.13 ; \mathrm{P}>0.05 ; 1997: \mathrm{r}^{2}=0.001 ; \mathrm{P}>0.05 ; 1998: \mathrm{r}^{2}=$ $0.001 ; \mathrm{P}>0.05$; Fig 4$)$.

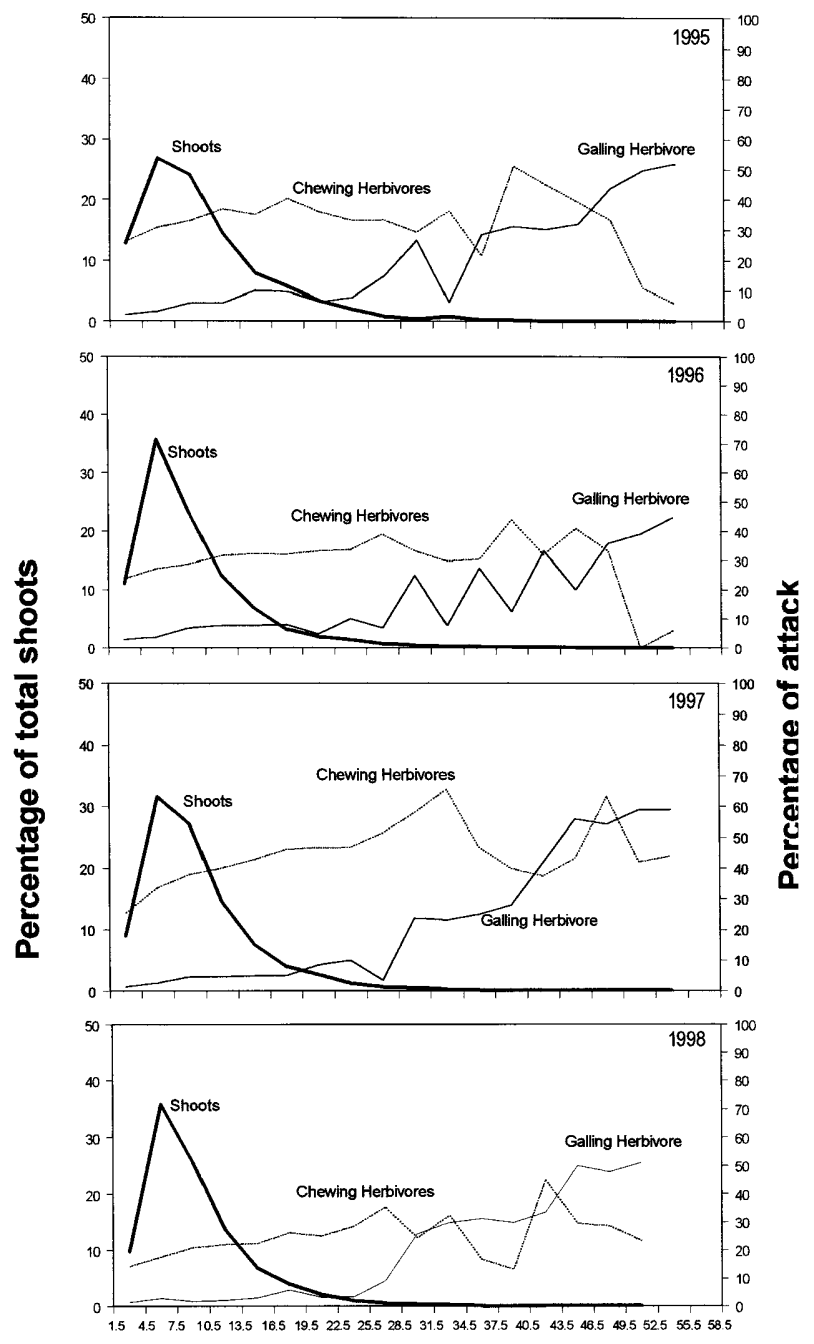

Shoot Length Class $(\mathrm{cm})$

Fig. 2. Proportion of shoots (thick line) in each shoot length class and the proportion of shoots attacked (dotted line) by two chewing species, Pantomorus sp. and Naupactus lar and a galling herbivore (narrow line), Contarinia sp., from 1995 to 1998. 


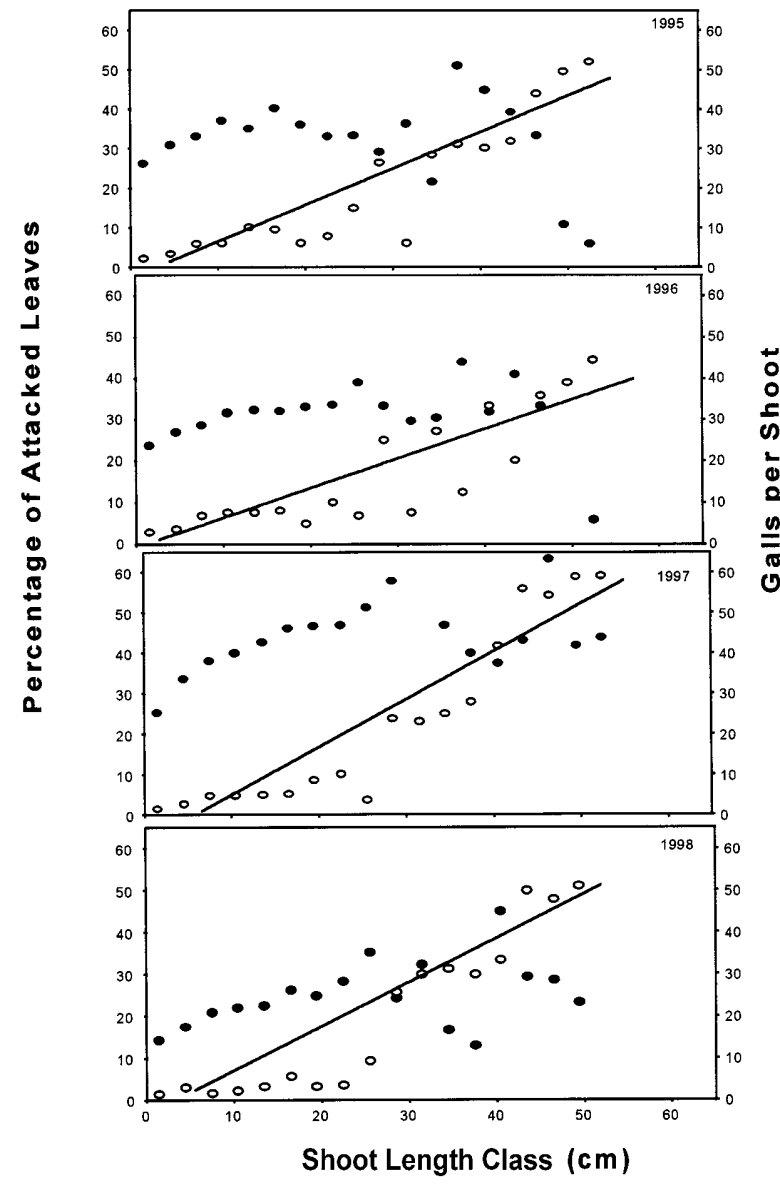

Fig. 3. The percentage of leaves attacked and number of galls per shoot on shoots of $B$. brevipes of different length classes from 1995 to 1998 . The tendency lines indicate the significant statistical relationships. Galling herbivore: open circles, and chewing herbivores: closed circles.

\section{DISCUSSION}

The plant vigour hypothesis relates to within-plantspecies variation, and the fact that many herbivores attack the most vigorous plant parts or plant individuals in a population is well documented (Price, 1997). Indeed, foresters have long recognized that young vigorous trees are often more susceptible than older plants to attack by herbivores. Kearsley \& Whitam (1989) showed that the number of the leaf beetle Chrysomela confluens is 400fold higher on juvenile narrowleaf cottonwood, Populus angustifolia, than on mature leaves. Many studies on other plants demonstrate that gall-forming insects attack long shoots more frequently than short shoots, and younger, vigorous plants more frequently than older, slower-growing plants in temperate regions (e.g., Craig et al., 1986; Price et al., 1987; Price, 1989), and in tropical regions (e.g, Faria et al., 1997; Madeira et al., 1997). Nevertheless, the results of some of these studies are contradictory, and some attempts to test the PVH have failed. Gonçalves-Alvim et al. (1999) tested the PVH using four neotropical species of galling insects and showed that different species responded differentially to shoot length, and just one species of a cecidomyiid galler behaved in

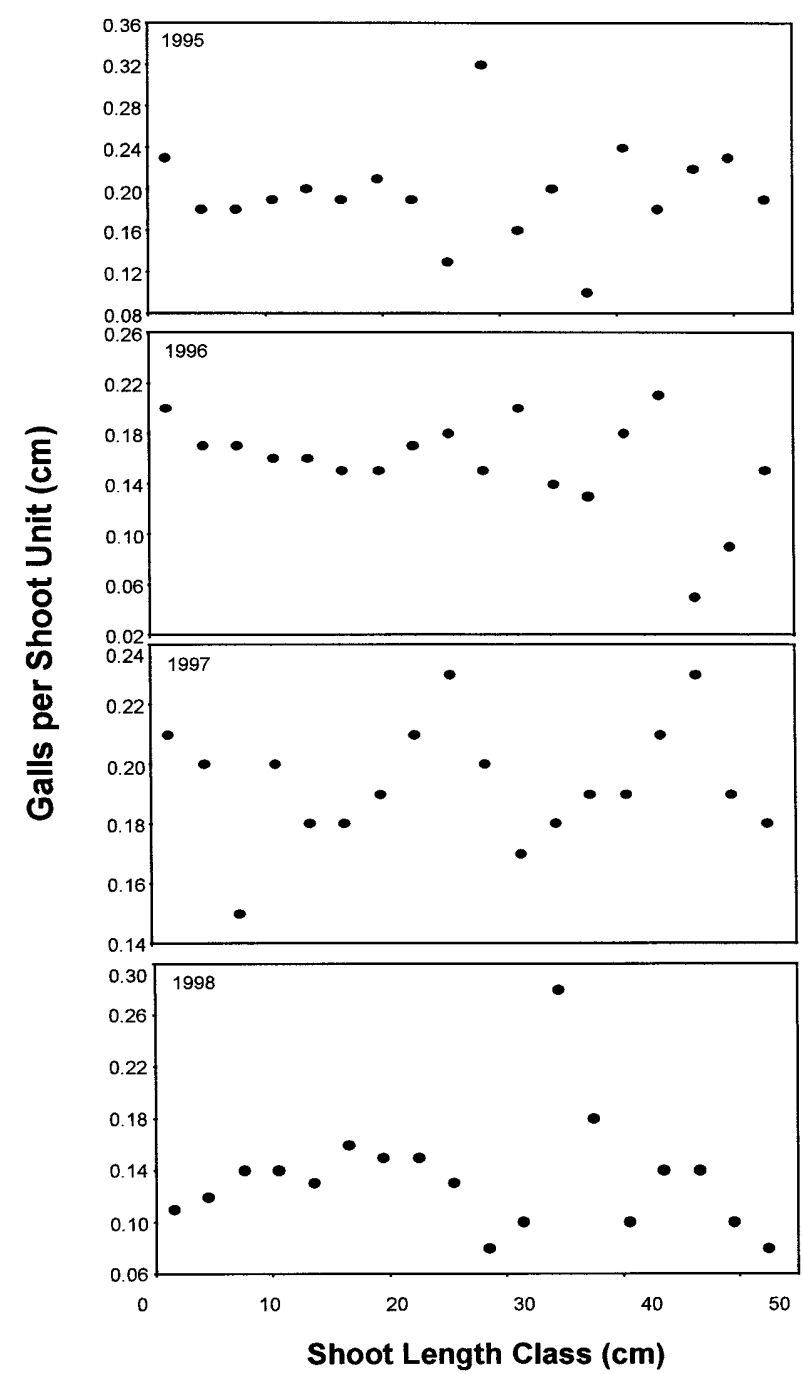

Fig. 4. The relationship between the number of galls per unit shoot length $(\mathrm{cm})$ and shoot length class in $B$. brevipes from 1995 to 1998.

concert with the PVH. Marini-Filho et al. (1997) found that a leaf-miner (Diptera: Agromyzidae) preferred shoot length located around the middle of the continuum between the stressed and vigorous plants.

Faria \& Fernandes (2001) suggested that the high attack rates commonly observed on the longest shoots - as proposed by the $\mathrm{PVH}$ - were not due to a preference by female herbivores, but due to the greater probability of the longest shoots being attacked. For example, the longer shoots offer more resources - leaves - for galling insects than the shorter shoots. Hence, the resource availability per unit of shoot length should be measured when testing the plant vigour hypothesis.

The two studied curculionid species of chewing herbivores did not prefer a particular shoot length: the attack was randomly distributed among shoot length classes. In addition, the pattern was consistent from year to year over a four year period. This study is in agreement with Cornelissen et al. (1997), which demonstrated that the pattern of attack over a two year period by another chewing herbivore - an undescribed species of Geometridae (Lepi- 
doptera) - was also not related to shoot length. In contrast to gall-forming herbivores, the chewing insects - such as Pantomorus sp. and Naupactus lar in which oviposition is spatially or temporally separated from larval development - typically do not show a preference for vigorously growing plant modules (see Preszler \& Price, 1995).

Two conditions of the PVH, however, are satisfied by most species of galling herbivores. They oviposit at the site of gall formation, and gall formation is associated with plant growth processes (Preszler \& Price, 1995). Although the longest shoots made a small proportion of the available shoot population, the gall former Contarinia sp. attacked them primarily. However, when the attack was related to shoot unit length, the preference for vigorous shoots was not expresed, showing that Contarinia sp. did not preferentially select the longer shoots of $B$. brevipes. Therefore, this work is in agreement with the studies of Cornelissen et al. (1997) and Gonçalves-Alvim et al. (1999), and supports the view that the pattern of attack by insect herbivores on shoots of various lengths may be viewed as a consequence of a continuum of responses.

ACKNOWLEDGEMENTS. We thank S. Vanim for the identifying the species of Coleoptera, A.L.F. Castro for field assistance and O.J. Marini-Filho for his good suggestions. This study was supported by CNPq (521772/95-8), FAPEMIG (1950/95), and Programa de Pós Graduação em Ecologia, Conservação \& Manejo de Vida Silvestre, ICB/UFMG.

\section{REFERENCES}

Azevedo L.G., Barbosa A.A.A., Oltverra A.L.C., Gorgonio A.S., Bedretchuk A.C., Siqueira F.B., Rizzo H.G., Silva I.S., Moura L.C., Araúro Filho M. \& Santos R.V. 1987: Ensaio metodológico de identificação e avaliação de unidades ambientais - A Estação Ecológica de Pipapitinga, MG. Secretaria Especial do Meio Ambiente, Embrapa-CPAC, Brasília, 37 pp.

Cornelissen T.G., Madeira B.G., Allain L.R., Lara A.C.F., AraúJo L.M. \& Fernandes G.W. 1997: Multiple responses of insect herbivores to plant vigor. Ciênc. Cult. 49: 285-288.

Cornelissen T.G. \& Fernandes G.W. 1998: Plant Hypersensitivity against tissue invasive insects: Bauhinia brevipes and Contarinia sp. interaction. In Csóka G., Mattson W.J., Stone G.N. \& Price P.W. (eds): The Biology of Gall Inducing Arthropods. US Department of Agriculture, Forest Service, North Carolina, pp. 144-152.

Craig T.P., Price P.W. \& ItAmI J.K. 1986: Resource regulation by a stem-galling sawfly on the arroyo willow. Ecology 67 : 419-426.

CraWleY M.J. 1989: Insect herbivores and plant population dynamics. Annu. Rev. Entomol. 34: 531-564.

Erten G. 1993: Vegetação de cerrado. In Pinto M.N. (ed.): Cerrado: Caracterização, ocupação e perspectivas. University of Brasília, Brasília, pp. 17-73.

Faria M.L. \& Fernandes G.W. 2001: Vigour of a dioecious shrub and attack by a galling herbivore. Ecol. Entomol. 26: $37-45$.

Faria M.L., Grelle C.E.V., Mendonça-Filmo C.V. \& FerNANDES G.W. 1997: Module selection by a scarabaeidae beetle on Erythroxylum suberosum in Serra do Cipó, Minas Gerais, Brazil. Ecotropicos 10: 29-32.
Fernandes G.W. 1998: Hypersensitivity as a phenotypic basis of plant induced resistance against a galling insect (Diptera: Cecidomyiidae). Envir. Entomol. 27: 260-267.

Gonçalves-Alvim S.J. \& Fernandes G.W. 2001: Biodiversity of galling insects: historical, community and habitat effects in the Neotropical savanna. Biodiv. Conserv. (in press).

Gonçalves-Alvim S.J., Faria M.L. \& Fernandes G.W. 1999: Relationships between four neotropical species of galling insects and shoot vigor. Anais Soc. Entomol. Bras. 28: $147-155$.

Goodland R. \& Ferri M.G. 1979: Ecologia do Cerrado. University of São Paulo, São Paulo, 108 pp.

KeARsLey M.C. \& Whitham T.G. 1989: Developmental changes in resistance to herbivory: implications for individuals and populations. Ecology 70: 422-434.

Madeira B.G., Cornelissen T.G., Faria M.L. \& Fernandes G.W. 1997: Insect herbivore preference for plant sex and modules in Baccharis concinna (Asteraceae). In Raman A. (ed.): Ecology and Evolution of Plant-Feeding Insects in Natural and Man-Made Environments. International Scientific Publications, New Delhi, pp. 135-145.

Marini-Filho O.J., SuIII E.R. \& Gomes-Filho A. 1997: Loose preference/performance linkage in a leaf-miner from Serra do Japí. Rev. Bras. Biol. 57: 435-440.

Mattson W.J. \& HaACK R.A. 1987: The role of drought in outbreaks of plant-eating insects. Bioscience 37: 110-118.

Prada M., Marini-Filho O.J. \& Price P.W. 1995: Insects in flower heads of Aspilia foliaceae (Asteraceae) after a fire in a central brazilian savanna: evidence for the plant vigor hypothesis. Biotropica 27: 513-518.

Preszler R.W. \& Price P.W. 1995: A test of plant vigor, plant stress, and plant-genotype effects on leaf-miner oviposition and performance. Oikos 74: 485-492.

PrICE P.W. 1989: Clonal development of coyote willow, Salix exigua (Salicaceae), and attack by the shoot galling sawfly, Euura exiguae (Hymenoptera: Tenthredinidae). Envir. Entomol. 18: 61-68.

Price P.W. 1991: The plant vigor hypothesis and herbivore attack. Oikos 62: 244-251

Price P.W. 1994: Phylogenetic constraints, adaptive syndromes, and emergent properties: from individuals to population dynamics. Oikos 36: 3-14.

Price P.W. 1997: Insect Ecology. 3rd ed. Wiley, New York.

Price P.W., Roininem H. \& Tahvanainem J. 1987: Plant age and attack by the bud galler, Euura mucronata. Oecologia 73 : 334-337.

Price P.W., Cobb N., Craig T.P., Fernandes G.W., Itami J., MopPeR S. \& Preszler R.W. 1990: Insect herbivore population dynamics on trees and shrubs: new approaches relevant to latent and eruptive species and life table development. In Bernays E. (ed.): Focus on Insect-Plant Interactions. Vol 3. CRC books, Boca Raton, FL, pp. 1-38.

Price P.W., Lewinshon T.M., Fernandes G.W. \& Benson W.W. 1991: Plant-Animal Interactions: Evolutionary Ecology in Tropical and Temperate Regions. Wiley, New York, 639 pp.

RHOADES D.F. 1979: Evolution of plant chemical defense against herbivores. In Rosenthal G.A. \& Janzen D.H. (eds): Herbivores - Their Interaction with Secondary Plant Metabolites. Academic Press, New York, pp. 4-54.

Whirte T.C.R. 1984: The abundance of invertebrate herbivores in relation to the availability of nitrogen in stressed food plants. Oecologia 63: 90-105.

Received September 14, 1999; revised December 17, 1999; accepted March 31, 2000 